\title{
Impact of Demographic Profile on Motive for Purchase of Laptop
}

\author{
Salma Shaheen ${ }^{1}$, Savita Gautam ${ }^{2}$ \\ ${ }^{1}$ Associate Professor, Faculty of Engineering and Technology, AMU, Aligarh, India \\ ${ }^{2}$ Assistant Professor, Faculty of Engineering and Technology, AMU, Aligarh, India
}

\begin{abstract}
In the present scenario laptop market is a highly competitive market in the world. Also, the consumer needs and expectations are changing rapidly. Therefore, for manufacturers of laptop it is difficult to survive in the market if they don't move forward according to the growing needs of their customers. The buying behaviour of consumer for Laptop plays significant role for manufacturers and marketers. Therefore this study would be useful for manufacturers and marketers so that they can build up successful marketing strategies to increase the market share. The present paper highlights the relationship between motive for purchase of laptop and demographic profile which includes occupation, age, qualification and gender. In this research paper, four null hypotheses have been prepared, tested and results are complied by using SPSS (Statistical Package for the Social Science). Finally present paper comes with some findings which shows the impact of demographic profile on purchase of laptop.
\end{abstract}

Keywords: Motive, Laptop, Purchase, Difference, Hypothesis

\section{Introduction to Hypotheses Testing}

This section presents an analysis of the proposed hypotheses using ANOVA and t-tests. In this section, each hypothesis is first listed which is followed by a Table that shows the result of the administered ANOVA (or t-test, wherever appropriate). This is followed by an inference stating whether the hypothesis is supported/accepted or not supported/rejected.

First, the set of four hypotheses have been analysed and presented. These are hypotheses Ho1 to Ho4. The set refers to hypotheses relating the variables with demographic profile like age, gender, occupation, and educational qualification.

\section{1Formulation of Hypotheses}

The following four hypotheses were designed for testing.

Ho1: There is no significant relationship between motive for purchase of laptop and occupation.

Ho2: There is no significant relationship between motive for purchase of laptop and age.

Ho3: There is no significant relationship between motive for purchase of laptop and qualification.

Ho4: There is no significant relationship between motive for purchase of laptop and gender.

\section{Administration of Questionnaire}

Two methods were adopted for administering the questionnaire. The first was contacting in person and second was through email.

Questionnaire was distributed in Aligarh city in the University (to academicians and home makers) and also in selected residential areas of Aligarh. Selection of departments in University and selection of residential areas was purely based on judgement of researcher. Therefore, methodology adopted was convenience and judgemental.
These respondents were contacted personally by the researcher.

Questionnaire was also sent by e-mail to the addresses on the researcher's e-mail list (address book). For this, first a list of addresses of these were made and the questionnaire was sent to all of them. Therefore, the methodology adopted in this case was census sampling [1].

Reminders in person were made to the respondents. A total of 100 questionnaires were distributed. Finally, 90 filled in questionnaire were received. The response rate is $90 \%$. A response rate of $25 \%$ is considered desirable for survey findings [2],[3]. As per Gupta, minimum sample size required is based on number of question items in the questionnaire [4].

Minimum sample size required $=$ four times the number of question items.

As number of questions in questionnaire used by researcher is 16 . Therefore, response rate of 64 is satisfactory.

\section{Data Analysis and Results}

Ho1: There is no significant relationship between motive for purchase of laptop and occupation.

Table 1.1: ANOVA Test for Testing Relationship between Motive and Occupation

\begin{tabular}{|c|c|c|c|c|c|}
\hline Occupation & $\mathrm{N}$ & Mean & $\begin{array}{c}\text { Std. } \\
\text { Deviation }\end{array}$ & $\mathrm{F}$ & Sig. \\
\hline Professional/Service & 61 & 3.5508 & 0.55576 & 0.283 & 0.838 \\
\hline Business & 7 & $\mathbf{3 . 6 0 0 0}$ & 0.57735 & & \\
\hline Home maker & 4 & 3.4000 & 0.83267 & & \\
\hline Any other & 18 & $\mathbf{3 . 6 5 5 6}$ & 0.56070 & & \\
\hline Total & 90 & 3.5689 & 0.56323 & & \\
\hline
\end{tabular}

Table 1.1 shows the result of ANOVA test, which is run to test the difference across different occupational group on the dimension of motive for purchase of laptop. It has been 


\section{International Journal of Science and Research (IJSR) \\ ISSN (Online): 2319-7064 \\ Index Copernicus Value (2013): 6.14 | Impact Factor (2014): 5.611}

found that the value of $F=0.283$ and Sig $=0.838$, which is more than 0.05 . Hence no difference exists.

Hypothesis Ho1 is supported (accepted); that is, there is no significant relation between motive for purchase of laptop and occupation. The descriptive statistics of the sample along with the mean values and the standard deviation are presented in Table 1.1. The Table shows the highest mean value was for the any other sector at 3.6556 followed by business sector which was at 3.6000 and then by Professional/Service at 3.5508 .

Ho2: There is no significant relationship between motive for purchase of laptop and age.

Table 1.2: ANOVA Test for Testing Relationship between Motiv and Age

\begin{tabular}{|c|c|c|c|c|c|}
\hline Age & $N$ & Mean & $\begin{array}{c}\text { Std. } \\
\text { Deviation }\end{array}$ & $F$ & Sig. \\
\hline Less than 25 years & 43 & $\mathbf{3 . 6 5 1 2}$ & 0.56920 & 0.681 & 0.566 \\
\hline 25-35 years & 38 & $\mathbf{3 . 5 1 5 8}$ & 0.57822 & & \\
\hline 35-45 years & 8 & 3.4000 & 0.47809 & & \\
\hline More than 45 years & 1 & 3.4000 &. & & \\
\hline Total & 90 & 3.5689 & 0.56323 & & \\
\hline
\end{tabular}

Table 1.2 shows the result of ANOVA test, which is run to test the difference across different age groups on the dimension of motive for purchase of laptop. It has been found that the value of $F=0.681$ and Sig $=0.566$, which is more than 0.05 . Hence no difference exists.

Hypothesis Ho2 is supported (accepted); that is, there is no significant relation between motive for purchase of laptop and age.

The descriptive statistics of the sample along with the mean values and the standard deviation are presented in Table 1.2. The Table shows the highest mean value was for the age group Less than 25 years which was at 3.6512 followed by the age 25-35 years which was at 3.5158.

Ho3: There is no significant relationship between motives for purchase of laptop and qualification.

Table 1.3 ANOVA Test for Testing Relationship between Motive and Qualification

\begin{tabular}{|c|c|c|c|c|c|}
\hline Qualification & N & Mean & $\begin{array}{c}\text { Std. } \\
\text { Deviation }\end{array}$ & F & Sig. \\
\hline $\begin{array}{c}\text { Technical/ Professional } \\
\text { Graduate }\end{array}$ & 47 & $\mathbf{3 . 6 0 8 5}$ & 0.53885 & 0.856 & 0.467 \\
\hline Non-Technical Graduate & 13 & 3.3385 & 0.60764 & & \\
\hline Post Graduate & 23 & $\mathbf{3 . 6 1 7 4}$ & 0.61766 & & \\
\hline Any Other & 7 & 3.5714 & 0.45356 & & \\
\hline Total & 90 & 3.5689 & 0.56323 & & \\
\hline
\end{tabular}

Table 1.3 shows the result of ANOVA test, which is run to test the difference across different qualification group on the dimension of motive for purchase of laptop. It has been found that the value of $\mathrm{F}=0.856$ and Sig $=0.467$, which is more than 0.05 . Hence no difference exists.

Hypothesis Ho3 is supported (accepted); that is, there is no significant relation between criteria for purchase of laptop and qualification.
The descriptive statistics of the sample along with the mean values and the standard deviation are presented in Table 1.3. The Table shows the higher mean value was for post graduate which was at 3.6174 followed by technical/professional graduate which was at 3.6085

Ho4: There is no significant relationship between motive for purchase of laptop and gender.

Table 1.4: T- Test for Testing Relationship between Motive and Gender

\begin{tabular}{|c|c|c|c|c|c|}
\hline Gender & $\mathrm{N}$ & Mean & $\begin{array}{c}\text { Std. } \\
\text { Deviation }\end{array}$ & $\mathrm{T}$ & $\begin{array}{c}\text { Sig. } \\
\text { (2-tailed) }\end{array}$ \\
\hline Male & 60 & 3.4700 & 0.58550 & -2.419 & 0.018 \\
\hline Female & 30 & 3.7667 & 0.46411 & -2.613 & 0.011 \\
\hline
\end{tabular}

Table 1.4 shows the result of independent sample $\mathrm{T}$ test, which is run to test the difference across different gender group on the dimension of motive for purchase of laptop. It has been found that the value of $\mathrm{T}=-2.419$ and $\mathrm{Sig}=0.018$, which is less than 0.05 . Hence difference exists.

Hypothesis Ho4 is not supported (rejected); that is, there is significant relation between motive for purchase of laptop and gender.

The descriptive statistics of the sample along with the mean values and the standard deviation are presented in Table 1.4. The Table shows the higher mean value was for female which was at 3.7667 while male was close behind with a mean value of 3.4700 .

\section{Summary of Hypotheses Testing}

This section presents a summary of the results obtained by administering ANOVA and t-tests on the proposed hypotheses. A Table 1.5 has been constructed to present in brief the various hypotheses and its results.

Table 1.5: Summary for Hypotheses with Demographic profile

\begin{tabular}{|c|c|c|c|c|}
\hline Parameter & Hypothesis & $\mathrm{F} / \mathrm{T}$ & Sig. & Results \\
\hline $\begin{array}{c}\text { Motives \& } \\
\text { Occupation }\end{array}$ & $\begin{array}{l}\text { Ho1: There is no } \\
\text { significant relationship } \\
\text { between motive for } \\
\text { purchase of laptop and } \\
\text { occupation. }\end{array}$ & 0.283 & 0.838 & Supported \\
\hline $\begin{array}{c}\text { Motives \& } \\
\text { Age }\end{array}$ & $\begin{array}{l}\text { Ho2: There is no } \\
\text { significant relationship } \\
\text { between motive for } \\
\text { purchase of laptop and } \\
\text { age. }\end{array}$ & 0.681 & 0.566 & Supported \\
\hline $\begin{array}{c}\text { Motives \& } \\
\text { qualification }\end{array}$ & $\begin{array}{c}\text { Ho3: There is no } \\
\text { significant relationship } \\
\text { between motive for } \\
\text { purchase of laptop and } \\
\text { qualification. }\end{array}$ & 0.856 & 0.467 & Supported \\
\hline $\begin{array}{l}\text { Motives \& } \\
\text { Gender }\end{array}$ & $\begin{array}{l}\text { Ho3: There is no } \\
\text { significant relationship } \\
\text { between motive for } \\
\text { purchase of laptop and } \\
\text { gender. }\end{array}$ & -2.419 & 0.018 & $\begin{array}{c}\text { Not } \\
\text { supported }\end{array}$ \\
\hline
\end{tabular}




\section{Conclusions}

This study concludes that the three Hypothesis Ho1, Ho2 and Ho3 which are for testing relationship between motive for purchase of laptop with occupation, Age, and qualification are supported/ accepted because value of $\mathrm{F}$ and Sig. is more than 0.05 .Therefore, this study reveals that there is no significant relationship between motive for purchase of laptop and various demographic profile like occupation, age, and qualification. This implies that occupation, age, and qualification does not play any role in purchase of laptop.

The study further concludes that Ho4 hypothesis is not supported/rejected and show relation between motive for purchase of laptop and gender. Here the value of $\mathrm{T}=-2.419$ and Sig. $(2$-tailed $)=0.018$.

\section{References}

[1]S. Shaheen, "Cost optimization in electronic toys manufacturing and marketing: A viable alternative for the women entrepreneurship," Ph.D thesis, (2015).

[2] J. Yu, H. Cooper, "A quantitative review of research design effects on response rates to questionnaires,"Journal of Marketing Research, 20, pp 36-44, (1983).

[3] M. K. Malhotra, V. Grover, "An assessment of survey research in POM: from constructs to theory," Journal of Operations Management, 16(17), pp 407- 425, (1998).

[4] S. P.Gupta, "Statistical Methods," Sultan Chand and sons publishers, New Delhi, (2003).

\section{Author Profile}

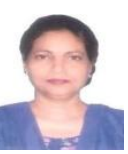

Salma Shaheen obtained her B.Sc. Engineering. and M. Sc. Engineering from Deptt. of Electronics Engg., Aligarh Muslim University (AMU), Aligarh, India in 1986 and 1994 respectively. She is currently an Associate Professor at the faculty of Engineering \& Technology, AMU, Aligarh. Her academic interests lie in areas of Multimedia Systems, Computer Networks, Entrepreneurship \& Optimization techniques. She has a teaching experience of more than 29 years.

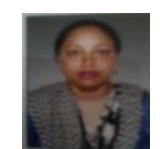

Savita Gautam completed her B,Tech (CSE) from NIT Kurukshetra in 2001 and MBA from UP Technical University in 2007 respectively. Currently working as Assistant Professor in the faculty of Engineering \& Technology, AMU, Aligarh. She has a teaching experience of more than 4yrs. Her research area includes Software Engg., Web Designing, Multimedia System and management. 